\title{
Seronegative Hepatitis C Virus Infection
}

\author{
Justyna Kaźmierczak • Agnieszka Pawełczyk • \\ Kamila Caraballo Cortes · Marek Radkowski
}

Received: 5 April 2013/Accepted: 25 October 2013/Published online: 9 November 2013

(C) The Author(s) 2013. This article is published with open access at Springerlink.com

\begin{abstract}
Hepatitis C virus (HCV) is a major cause of liver disease worldwide. The routine diagnostics identifying $\mathrm{HCV}$ infection include testing for specific anti-HCV antibodies by enzyme-linked immnunosorbent assay and viral genetic material in serum or plasma. However, a small proportion of patients persistently infected with $\mathrm{HCV}$, in whom anti-HCV are undetectable, constitute a serious diagnostic and possibly epidemiologic problem, as they could facilitate pathogen spread in the population. This type of infection is termed seronegative or serosilent. Seronegative HCV infection is currently of great interest to both scientists and physicians. The review presents epidemiological data concerning the prevalence of seronegative $\mathrm{HCV}$ infection in HIV/HCV co-infected individuals, hemodialysis patients, and blood and organ donors. The possible mechanisms behind this atypical course of infection are discussed. Furthermore, the differences between seronegative and occult infections and prolonged seroconversion are explained.
\end{abstract}

Keywords HCV · Anti-HCV · HCV RNA ·

Seronegative infection · Diagnostics

\begin{tabular}{ll}
\multicolumn{2}{l}{ Abbreviations } \\
EIA & Enzyme immunoassay \\
ELISA & Enzyme-linked immunosorbent assay \\
HCV & Hepatitis C virus \\
HCV RNA & Hepatitis C viral genetic material \\
HIV & Human immunodeficiency virus
\end{tabular}

J. Kaźmierczak $(\bowtie) \cdot$ A. Pawełczyk · K. C. Cortes · M. Radkowski

Department of Immunopathology of Infectious and Parasitic Diseases, Medical University of Warsaw, Warsaw, Poland e-mail: jkazmierczak@wum.edu.pl $\begin{array}{ll}\text { PBMC } & \text { Peripheral blood mononuclear cells } \\ \text { RIBA } & \text { Recombinant immunoblot assay } \\ \text { PCR } & \text { Polymerase chain reaction }\end{array}$

\section{Introduction}

Hepatitis $\mathrm{C}$ virus (HCV) is an etiologic factor of acute and chronic hepatitis, liver cirrhosis and hepatocellular carcinoma (Flisiak et al. 2011; Hu and Tong 1999). The estimated number of humans infected with the virus reaches 170 million worldwide including 0.7 million in Poland (Flisiak et al. 2011; Zagożdżon et al. 2009). Although HCV is a primary hepatotropic pathogen, its replication has been demonstrated in other cells, most notably in peripheral blood mononuclear cells (PBMC) and macrophages (Azzari et al. 2008; Chary et al. 2012; Laskus et al. 2000, 2004; Page et al. 2010; Revie and Salahuddin 2011; Zayed et al. 2010).

Diagnostic criteria for hepatitis $\mathrm{C}$ virus infection include the presence of anti-HCV antibodies and viral genetic material (HCV RNA) in blood serum. However, in some patients, the anti-HCV antibodies are absent despite the persistent presence of HCV RNA. Such status is termed "seronegative" or "serosilent" HCV infection and may be associated with clinical conditions such as human immunodeficiency virus (HIV) co-infection, hemodialysis and organ transplantation, but sporadically it is also seen in blood donors and other patients (Brojer et al. 2001; Schneeberger et al. 1998; Thomson et al. 2009; Tugwell et al. 2005).

Seronegative HCV infection represents a serious clinical and epidemiological problem and the pathogenetic mechanisms underlying this condition are poorly understood. 
Hepatitis C Virus Diagnostics

Routinely used diagnostic methods for $\mathrm{HCV}$ infection are based on the detection of anti-HCV antibodies and HCV RNA in blood serum (Pawlotsky et al. 1998). At present, antibodies are detected by third-generation enzyme immunoassay (EIA) or enzyme-linked immunosorbent assay (ELISA) using recombinant core and non-structural proteins NS3, NS4 and NS5 HCV (Albeldawi et al. 2010; Mondelli et al. 2005; Muñoz Espinosa 2002). To confirm positive serological test result, recombinant immunoblot assay (RIBA) test was routinely used (Pawlotsky et al. 1998; Van der Poel et al. 1991). However, molecular tests verifying the presence of HCV RNA are currently recommended (Tuaillon et al. 2010). The main limitation of diagnostic tests, based on the detection of antibodies (ELISA, RIBA), is lack of HCV infection identification during the serological window phase, i.e., during the period when the antibody level is below the detection limit of these tests (Nübling et al. 2002). This period ranges from 6 weeks (Morand et al. 2001; Thomson 2009) to 9 months (Arrojo et al. 2003), but is usually no longer than 12 weeks (Lauer and Walker 2001; Schreiber et al. 1996). It should be noted that some individuals with immunosuppression need even more time to seroconvert. Currently used tests with improved sensitivity have narrowed the serological window period following a primary acute-phase infection. The challenge is how to interpret partial or incomplete antibody seroconversions characterized by indeterminate test results on supplemental immunoblot assays (Carreño et al. 2012).

In contrast, $\mathrm{HCV}$ genetic material may be detected by means of molecular methods (NAT-nucleic acid testing) as early as 7-10 days post-infection (Schröter et al. 1997; Takedai et al. 2008). They include qualitative polymerase chain reaction (PCR), transcription-mediated amplification (TMA) and quantitative bDNA assay (branched-chain amplification) and real-time PCR (Scott and Gretch 2007).

Molecular methods are characterized by high specificity and sensitivity (detection limit up to $5 \mathrm{IU} / \mathrm{mL}$ ); (Ross et al. 2001; Scott and Gretch 2007). In contrast to serological methods, molecular tests enable detection of viral infection during the very early phase (serological window period). They are used to confirm HCV infection, measure viral load and determine viral genotype necessary for treatment decisions. Finally, they allow monitoring the effectiveness of antiviral treatment (Higuchi et al. 2002; Stapleton et al. 1999).

Pathogenesis of Seronegative HCV Infection

In most cases, both anti-HCV antibodies and HCV RNA are detectable in serum (Lok and Gunaratnam 1997; Pondé
2013). However, in some subjects anti-HCV antibodies are not detectable, even during the late infection phase. Reasons for this unusual condition may be delayed seroconversion (longer than 3 months post-infection), which sometimes may be prolonged to several years (Stapleton et al. 1999). The latter phenomenon is frequently found in patients with immune dysfunctions (immunosuppression) and intravenous drug users (Arrojo et al. 2003; Beld et al. 1999). In the latter group, anti-HCV antibodies may become detectable after superinfection with a different HCV genotype strain (Beld et al. 1999).

It is likely that prolonged or delayed seroconversion period may be due to low $\mathrm{HCV}$ viral load levels not sufficient for effective stimulation of the immune system. Low $\mathrm{HCV}$ antigen levels were reported to be a cause of weak recognition of the viral antigens by $\mathrm{T}$ helper cells and, consequently, low or absent B cell response (Mientjes et al. 1991).

The seronegative $\mathrm{HCV}$ infection due to the lack of production of specific anti-HCV antibodies is different from the situation in which the antibodies are synthesized and present in the blood, but in amounts not detectable by routinely used diagnostic tests. For instance, the sensitivity of third-generation EIA test is $97-99.9 \%$, which is very high but not complete (Ellethy et al. 2012).

Another reason for seronegativity may be the presence of immune complexes of antibodies and viral antigens, resulting in very low levels of free, circulating antibodies. This may occur in patients with relatively low anti-HCV response with simultaneous massive virus replication and antigen production. To overcome this problem, procedures for dissociation of immune complexes to "liberate" antibodies are available, although they are not routinely employed (Alnaqy et al. 2006; Pawlotsky et al. 1996; Troisi and Hollinger 1997).

While the majority of studies concerning seronegative $\mathrm{HCV}$ infection are focused on patients displaying immune dysfunctions, such as hypogammaglobulinemia (George et al. 2002; Post et al. 2004; Rossi et al. 1997), subjects coinfected with HIV or transplant organ recipients (Bonacini et al. 2001; Larouche et al. 2012; Wright et al. 1994), some authors suggested that inherent properties of particular $\mathrm{HCV}$ strains may be responsible. Thus, seronegative HCV infection may be a result of the presence of viral antigenic variants which stimulate the production of antibodies not recognized in standard serologic tests (Alnaqy et al. 2006; Pawlotsky et al. 1996). Moreover, some HCV strains may evade host immune responses or directly infect cells of the immune system ( $\mathrm{T}$ and B cells); (Larouche et al. 2012; Sarhan et al. 2012). Genetic predispositions or defects affecting humoral responses against $\mathrm{HCV}$ were also suggested (Alnaqy et al. 2006; Larouche et al. 2012; Pawlotsky et al. 1996). Finally, it was also documented that 
seronegative infection may develop as a result of immune tolerance to $\mathrm{HCV}$ antigens, acquired in early life through vertical HCV transmission (Larouche et al. 2012).

\section{Epidemiology of Seronegative HCV Infection}

The majority of epidemiological studies of seronegative HCV infection refer to HIV co-infected individuals, hemodialyzed patients, and organ and blood donors. The prevalence of this phenomenon is summarized in Table 1.

\section{HIV/HCV Co-Infection}

The concomitant infection with HIV and HCV is common, particularly among intravenous drug users and hemophiliacs, and ranges at 7-85\% (George et al. 2002; Vachon et al. 2008). For this reason, all HIV-infected patients should be monitored for the presence of anti-HCV antibodies (Hadlich et al. 2007; Vachon et al. 2008).

Some HCV RNA-positive HIV co-infected patients remain anti-HCV negative long after exposure. The lack of anti-HCV seroconversion in these patients is believed to be due to immune dysfunction secondary to HIV infection (Chamie et al. 2007; Sorbi et al. 1996).

In a pooled analysis of four studies, the frequency of HCV RNA positivity and concomitant absence of antiHCV antibodies among HIV-infected patients was $3.2 \%$ (Chamie et al. 2007); in one study, it was reported to be as high as $13.2 \%$ (Bonacini et al. 2001; George et al. 2002; Hadlich et al. 2007). Seronegative HCV infection in HIVinfected individuals is more common in patients with $\mathrm{CD}^{+}$cells count below $100 / \mu \mathrm{L}$ and more advanced immunodeficiency (Hadlich et al. 2007). Among intravenous drug users exhibiting increased levels of alanine aminotransferase activity and decrease of $\mathrm{CD}^{+}$cells counts below $200 / \mu \mathrm{L}$, the prevalence of seronegative infection is as high as $24 \%$ (Chamie et al. 2007). This indicates that molecular techniques should be widely employed as first-line diagnostic methods, especially among patients with elevated activity of liver enzymes (George et al. 2002).

\section{Hemodialyzed Patients}

Hemodialyzed patients are a high-risk group for parenterally transmitted infections, including $\mathrm{HCV}$ infection. Immune dysfunctions are common among these patients and include aberrant B cell activation resulting in delayed synthesis of antibodies and/or their low levels in blood (Fabrizi et al. 2012; Schneeberger et al. 2000). It is estimated that $1-60 \%$ of hemodialyzed patients are $\mathrm{HCV}$ infected (Hanuka et al. 2002; Kelley et al. 2002). The presence of HCV RNA among seronegative patients is found in 1-15\% of the cases (Carneiro et al. 2001; Fabrizi et al. 1999; Hanuka et al. 2002; Schröter et al. 1997).

The high prevalence of seronegative HCV infections in this group of patients warrants wider use of molecular tests for diagnostic purposes.

\section{Organ and Blood Donors}

Despite many precautions and procedures reducing the transmission of infections, organ transplantation still carries a risk of $\mathrm{HCV}$ infection. Among anti-HCV negative organ donors, HCV RNA is detectable in less than $1 \%$ (0.2-0.9\%); (Aswad et al. 2005; Challine et al. 2004); however, immune dysfunction present in transplant recipients entails an increased risk of infection. Molecular testing for HCV RNA and viral core antigen are not routinely performed in organ donor candidates, mostly because of high costs and complex diagnostic procedures (Challine et al. 2004). However, since a single donor can be a source of graft material for multiple recipients, the prospective donors should be carefully screened for HCV infection with molecular methods (Tugwell et al. 2005).

According to different sources, the frequency of seronegative $\mathrm{HCV}$ infection among blood donors in developed countries ranges at 0.0004-0.08\% (Brojer 2005; Legler et al. 2000; Seyfried et al. 2005; Stramer et al. 2004). One of the most important means to control the spread of $\mathrm{HCV}$ infection is molecular testing of donors' blood (Brojer 2005; Letowska et al. 2009). Detection of anti-HCV antibodies in blood donors has been introduced in the early 1990s of the last century (Seyfried et al. 2005).

Table 1 The prevalence of seronegative HCV infection

\begin{tabular}{lcc}
\hline Population & Seronegative HCV infection (\%) & References \\
\hline HIV/HCV co-infected individuals & $3.2-13.2$ & $\begin{array}{c}\text { Bonacini et al. (2001), Chamie et al. (2007), } \\
\text { George et al. (2002), Hadlich et al. (2007) } \\
\text { Carneiro et al. (2001), Fabrizi et al. (1999), } \\
\text { Hanuka et al. (2002), Schröter et al. (1997) } \\
\text { Hemodialyzed patients }\end{array}$ \\
$\begin{array}{lcl}\text { Organ donors } \\
\text { Blood donors }\end{array}$ & $0.2-0.9$ & $\begin{array}{c}\text { Aswad et al. 2005, Challine et al. 2004, Legler et al. 2000 } \\
\text { Brojer 2005, Seyfried et al. 2005, Stramer et al. 2004 }\end{array}$ \\
\hline
\end{tabular}


Molecular testing, aimed at the detection of $\mathrm{HCV}$ infection, was widely criticized for its high cost. However, since the year 2000 it is obligatory in the majority of countries, including Poland (Alnaqy et al. 2006; Brojer 2005; Challine et al. 2004). Its introduction for each blood collection significantly increased the safety of blood and blood-derived product transfusion (Alnaqy et al. 2006; Brojer 2005). For economic reasons, pooled testing of plasma collected from donors (48 or more) has been routinely performed. In case HCV RNA is detected in the pooled specimens, the individual samples are tested separately. Currently used procedures recommend performing molecular testing of single samples; however, there are variations depending on the laboratory and kits employed. It should be stressed that "dilution" of material when mixing multiple samples may lead to false-negative results especially when single HCV-positive sample with low viremia is present in the pool (Brojer 2005). One can expect that simplification and cost reduction of molecular tests will promote their universal use.

\section{Specific Memory Cells in HCV Infection}

Potent $\mathrm{CD}^{+}{ }^{+}$and $\mathrm{CD}^{+}$cellular responses specific to $\mathrm{HCV}$ antigens may lead to virus elimination (Bertoletti and Ferrari 2003; Chang 2003; Meyer et al. 2007; Thimme et al. 2001; Zhang et al. 2009). It was demonstrated that individuals eliminating $\mathrm{HCV}$ infection display stronger $\mathrm{T}$ cell responses than those chronically infected (Lauer and Walker 2001; Lechner et al. 2000; Meyer et al. 2007; Urbani et al. 2006). Strong and long-lasting $\mathrm{CD}^{+}$and $\mathrm{CD}^{+}$responses are present in more than $80 \%$ of patients who cleared HCV infection (Zhang et al. 2009). T cell responses may persist as long as 20 years after viral clearance providing evidence of past $\mathrm{HCV}$ infection (Takaki et al. 2000; Wedemeyer et al. 2002).

Specific cellular responses were also observed among high-risk groups for $\mathrm{HCV}$ infection and/or subjects exposed to $\mathrm{HCV}$ who remained persistently negative for HCV RNA and anti-HCV antibodies. Examples include sexual partners and family members of $\mathrm{HCV}$-infected patients and laboratory workers (Bronowicki et al. 1997; Koziel et al. 1997; Scognamiglio et al. 1999). These cases may represent specific immune memory after a subclinical course of infection and subsequent spontaneous viral clearance (Scognamiglio et al. 1999).

The absence of specific anti-HCV antibodies and HCV RNA in subjects displaying specific cellular responses may be a result of exposure dose that was insufficient to induce viral hepatitis or even trigger humoral response. Broad cellular responses to many $\mathrm{HCV}$ antigens were also found in seronegative prisoners who were transiently HCV RNA positive in blood, but eventually cleared the infection. It was also suggested that the absence of anti-HCV antibodies could be a consequence of massive cytotoxic $\mathrm{T}$ responses directed against virus-infected B cells (Scognamiglio et al. 1999).

According to some studies, $\mathrm{HCV}$ elimination is not necessarily the result of strong cellular responses, as some patients who spontaneously cleared the virus showed weak or even absent $\mathrm{CD}^{+}$and $\mathrm{CD}^{+}$responses against viral antigens (Meyer et al. 2007).

\section{Occult HCV Infection}

"Occult HCV infection" is characterized by the absence of anti-HCV antibodies and HCV RNA in the blood with concomitant presence of viral genetic material in hepatocytes and elevated activity of liver enzymes indicating an ongoing inflammatory process in the liver (Castillo et al. 2004; Comar et al. 2006; Esaki et al. 2004; Quiroga et al. 2006, 2009). The term "occult HCV infection" is also sometimes used in case of individuals who cleared HCV infection, but display the presence of HCV RNA in liver tissue and anti-HCV antibodies in serum (Carreño 2006). The latter should perhaps be considered a particular clinical representation of chronic $\mathrm{HCV}$ infection characterized by low replication, or a late stage of infection directly preceding viral elimination.

Typical features of occult HCV infection include lower liver enzymes activity and lower percentage of infected hepatocytes than is typical for clinically overt infection (Pardo et al. 2007). Most patients with occult HCV infection display specific $\mathrm{CD}^{+}$and $\mathrm{CD}^{+}$responses and, surprisingly, their memory $\mathrm{T}$ cell activation is much more frequent than in those with typical clinical course. It is suspected that these cells may be involved in viral replication control to undetectable levels (Quiroga et al. 2006).

The estimated frequency of occult $\mathrm{HCV}$ infection among patients displaying hepatic dysfunction may be as high as $57 \%$ (Castillo et al. 2004). In the majority of them HCV RNA is also present in PBMC (70 \%), and in over half of the latter $(61 \%)$ markers of active viral replication were detected in this extrahepatic compartment (Castillo et al. 2004, 2005).

Due to the difficulties in detecting occult HCV infection with standard laboratory tests, all data regarding this phenomenon come from research studies. Nevertheless, this form of infection seems to be distributed worldwide and its prevalence among the healthy population was reported to be as high as $3.3 \%$ (Carreño et al. 2012; De Marco et al. 2009) and even higher among patients suffering from cryptogenic hepatitis or cryptogenic cirrhosis with hepatocellular carcinoma (10-74\%); (Bokharaei-Salim et al. 2011; Comar et al. 2006; Esaki et al. 2004; Idrees et al. 2011; Zaghloul and El-Sherbiny 2010). 


\section{Conclusions}

Seronegative HCV infection represents a significant clinical problem. One possible consequence of seronegative infection may be a continuous transmission of $\mathrm{HCV}$ in the low-risk population (Larouche et al. 2012; Stapleton et al. 1999; Wiese et al. 2000).

The pathogenesis of seronegative HCV infection is not fully understood. Most likely it is a result of immune dysfunctions resulting in the inability to properly recognize $\mathrm{HCV}$ antigens and produce specific antibodies. Another mechanism could be infection with atypical viral strain (Alnaqy et al. 2006; Beld et al. 1999; Pawlotsky et al. 1996).

To optimize HCV diagnostics, including seronegative infections, the following issues must be considered: patient's immune status, type of biological sample collected, time point of sample collection, possibility of delay in antibody production and the sensitivity limit of different diagnostic tests. The diagnostic procedures based on high sensitivity molecular HCV RNA detection should be more widely introduced, especially among high risk groups and organ donors.

As viral blood levels typically usually fluctuate and may temporarily drop below the level of detection, in some initially HCV RNA-negative cases the testing should be repeated. In patients with persistent hepatic dysfunction of unknown etiology, the search for viral RNA in samples other than blood (most notably liver and PBMC) should be considered. Although cumbersome in clinical practice, these procedures could contribute to improvements in $\mathrm{HCV}$ infection detection and consequently facilitate the development of strategies aimed at decreasing the transmission frequency of this virus.

Conflict of interest All authors of this article declare that they do not have any competing financial interests in relation to the presented work.

Open Access This article is distributed under the terms of the Creative Commons Attribution License which permits any use, distribution, and reproduction in any medium, provided the original author(s) and the source are credited.

\section{References}

Albeldawi M, Ruiz-Rodriguez E, Carey WD (2010) Hepatitis C virus: prevention, screening, and interpretation of assays. Clevel Clin $\mathrm{J}$ Med 77:616-626

Alnaqy A, Al-Harthy S, Kaminski G et al (2006) Detection of serum antibodies to hepatitis C virus in 'false-seronegative' blood donors in Oman. Med Princ Pract 15:111-113

Arrojo IP, Pareja MO, Orta MD et al (2003) Detection of a healthy carrier of $\mathrm{HCV}$ with no evidence of antibodies for over four years. Transfusion 43:953-957
Aswad S, Khan NS, Comanor L et al (2005) Role of nucleic acid testing in cadaver organ donor screening: detection of hepatitis $\mathrm{C}$ virus RNA in seropositive and seronegative donors. J Viral Hepat 12:627-634

Azzari C, Moriondo M, Indolfi G et al (2008) Higher risk of hepatitis $\mathrm{C}$ virus perinatal transmission from drug user mothers is mediated by peripheral blood mononuclear cell infection. J Med Virol 80:65-71

Beld M, Penning M, van Putten M et al (1999) Low levels of hepatitis C virus RNA in serum, plasma, and peripheral blood mononuclear cells of injecting drug users during long antibody-undetectable periods before seroconversion. Blood 94:1183-1191

Bertoletti A, Ferrari C (2003) Kinetics of the immune response during HBV and HCV infection. Hepatology 38:4-13

Bokharaei-Salim F, Keyvani H, Monavari SH et al (2011) Occult hepatitis $\mathrm{C}$ virus infection in Iranian patients with cryptogenic liver disease. J Med Virol 83:989-995

Bonacini M, Lin HJ, Hollinger FB (2001) Effect of coexisting HIV-1 infection on the diagnosis and evaluation of hepatitis $\mathrm{C}$ Virus. J Acquir Immune Defic Syndr 26:340-344

Brojer E (2005) Serological and molecular markers of HCV infection in Polish blood donors. Przegl Epidemiol 59:511-517

Brojer E, Liszewski G, Niznik A et al (2001) Detection of HCV core antigen in HCV RNA positive, anti-HCV negative blood donations from Polish blood donors. Transfusion 41:304

Bronowicki JP, Vetter D, Uhl G et al (1997) Lymphocyte reactivity to hepatitis $\mathrm{C}$ virus $(\mathrm{HCV})$ antigens shows evidence for exposure to $\mathrm{HCV}$ in $\mathrm{HCV}$-seronegative spouses of $\mathrm{HCV}$-infected patients. J Infect Dis 176:518-522

Carneiro MA, Martins RM, Teles SA et al (2001) Hepatitis C prevalence and risk factors in hemodialysis patients in Central Brazil: a survey by polymerase chain reaction and serological methods. Mem Inst Oswaldo Cruz 96:765-769

Carreño V (2006) Occult hepatitis C virus infection: a new form of hepatitis C. World J Gastroenterol 12:6922-6925

Carreño V, Bartalomé J, Castillo I et al (2012) New perspectives in occult hepatitis C infection. World J Gastroentrol 18:2887-2894

Castillo I, Pardo M, Bartolome J et al (2004) Occult hepatitis C virus infection in patients in whom the etiology of persistently abnormal results of liver-function tests is unknown. J Infect Dis 189:7-14

Castillo I, Rodriguez-Inigo E, Bartolome J et al (2005) Hepatitis C virus replicates in peripheral blood mononuclear cells of patients with occult hepatitis C virus infection. Gut 54:682-685

Challine D, Pellegrin B, Bouvier-Alias M et al (2004) HIV and hepatitis $\mathrm{C}$ virus RNA in seronegative organ and tissue donors. Lancet 364:1611-1612

Chamie G, Bonacini M, Bangsberg DR et al (2007) Factors associated with seronegative chronic hepatitis $\mathrm{C}$ virus infection in HIV infection. Clin Infect Dis 44:577-583

Chang KM (2003) Immunopathogenesis of hepatitis $C$ virus infection. Clin Liver Dis 7:89-105

Chary A, Winters MA, Eisen R et al (2012) Quantitation of hepatitis $\mathrm{C}$ virus RNA in peripheral blood mononuclear cells in HCVmonoinfection and HIV/HCV-coinfection. J Med Virol 84:431-437

Comar M, Molin GD, D'Agaro P et al (2006) HBV, HCV, and TTV detection by in situ polymerase chain reaction could reveal occult infection in hepatocellular carcinoma: comparison with blood markers. J Clin Pathol 59:526-529

De Marco L, Gillio-Tos A, Fiano V et al (2009) Occult HCV infection: an unexpected finding in a population unselected for hepatic disease. PLoS ONE 4:e8128

Ellethy AT, Sliem HA, Hassan GM (2012) Updated molecular diagnosis of chronic hepatitis C. J Gastroenterol Hepatol 1:147-152 
Esaki T, Suzuki N, Yokoyama K et al (2004) Hepatocellular carcinoma in a patient with liver cirrhosis associated with negative serum HCV tests but positive liver tissue HCV RNA. Intern Med 43:279-282

Fabrizi F, Martin P, Dixit V et al (1999) Detection of de novo hepatitis $\mathrm{C}$ virus infection by polymerase chain reaction in hemodialysis patients. Am J Nephrol 19:383-388

Fabrizi F, Dixit V, Messa P et al (2012) Hepatitis C-related liver disease in dialysis patients. Contrib Nephrol 176:42-53

Flisiak R, Halota W, Horban A et al (2011) Prevalence and risk factors of HCV infection in Poland. Eur J Gastroenterol Hepatol 23:1213-1217

George SL, Gebhardt J, Klinzman D et al (2002) Hepatitis C virus viremia in HIV-infected individuals with negative $\mathrm{HCV}$ antibody tests. J Acquir Immune Defic Syndr 31:154-162

Hadlich E, Alvares-Da-Silva, Dal Molin RK et al (2007) Hepatitis C virus $(\mathrm{HCV})$ viremia in $\mathrm{HIV}$-infected patients without $\mathrm{HCV}$ antibodies detectable by third-generation enzyme immunoassay. J Gastroenterol Hepatol 22:1506-1509

Hanuka N, Sikuler E, Tovbin D et al (2002) Hepatitis C virus infection in renal failure patients in the absence of anti-hepatitis $\mathrm{C}$ virus antibodies. J Viral Hepat 9:141-145

Higuchi M, Tanaka E, Kiyosawa K (2002) Epidemiology and clinical aspects on hepatitis C. Jpn J Infect Dis 55:69-77

Hu KQ, Tong MJ (1999) The long-term outcomes of patients with compensated hepatitis C virus-related cirrhosis and history of parenteral exposure in the United States. Hepatology 29:1311-1316

Idrees M, Lal A, Malik FA et al (2011) Occult hepatitis C virus infection and associated predictive factors: the Pakistan experience. Infect Genet Evol 11:442-445

Kelley VA, Everett-Kitchens J, Brannon LE et al (2002) Lack of seronegative hepatitis $\mathrm{C}$ virus infections in patients with chronic renal failure. Transplantation 74:1473-1475

Koziel MJ, Wong DK, Dudley D et al (1997) Hepatitis C virusspecific cytolytic $\mathrm{T}$ lymphocyte and $\mathrm{T}$ helper cell responses in seronegative persons. J Infect Dis 176:859-866

Larouche A, Gaetan G, El-Bilali N et al (2012) Seronegative hepatitis $\mathrm{C}$ virus infection in a child infected via mother-to-child transmission. J Clin Microbiol 50:2515-2519

Laskus T, Radkowski M, Piasek A et al (2000) Hepatitis C virus in lymphoid cells of patients coinfected with human immunodeficiency virus type 1: evidence of active replication in monocytes/ macrophages and lymphocytes. J Infect Dis 181:442-448

Laskus T, Radkowski M, Jablonska J et al (2004) Human immunodeficiency virus facilitates infection/replication of hepatitis $\mathrm{C}$ virus in native human macrophages. Blood 103:3854-3859

Lauer GM, Walker BD (2001) Hepatitis C virus infection. N Engl J Med 345:41-52

Lechner F, Wong DK, Dunbar PR et al (2000) Analysis of successful immune responses in persons infected with hepatitis $\mathrm{C}$ virus. J Exp Med 191:1499-1512

Legler TJ, Riggert J, Simson G et al (2000) Testing of individual blood donations for HCV RNA reduces the residual risk of transfusiontransmitted HCV infection. Transfusion 40:1192-1197

Letowska M, Rosiek A, Gronowska A et al (2009) Hepatitis C virus (HCV) core antigen detection in HCV RNA-positive/anti-HCVnegative Polish blood donors identified by nucleic acid testing. Transfusion 49:2241-2242

Lok AS, Gunaratnam NT (1997) Diagnosis of hepatitis C. Hepatology 26:48S-56S

Meyer MF, Wedemeyer H, Monazahian M et al (2007) Prevalence of hepatitis $\mathrm{C}$ in a German prison for young men in relation to country of birth. Epidemiol Infect 135:274-280

Mientjes GH, Miedema F, van Ameijden EJ et al (1991) Frequent injecting impairs lymphocyte reactivity in HIV-positive and HIV-negative drug users. AIDS 5:35-41
Mondelli MU, Cerino A, Cividini A (2005) Acute hepatitis C: diagnosis and management. J Hepatol 42(Suppl(1)):S108-S114

Morand P, Dutertre N, Minazzi H et al (2001) Lack of seroconversion in a health care worker after polymerase chain reactiondocumented acute hepatitis $\mathrm{C}$ resulting from a needlestick injury. Clin Infect Dis 33:727-729

Muñoz Espinosa LE (2002) Diagnosis of hepatitis C virus infection. Rev Gastroenterol Mex 67(Suppl 2):S29-S35

Nübling M, Unger G, Chudy M et al (2002) Sensitivity of HCV core antigen and HCV RNA detection in the early infection phase. Transfusion 42:1037-1045

Page EE, Cox A, Atkins M et al (2010) Clearance of hepatitis C virus RNA from serum in HIV/hepatitis $C$ virus coinfection indicates eradication from peripheral blood mononuclear cells. AIDS 24:1267-1271

Pardo M, Lopez-Alcorocho JM, Rodriguez-Inigo E et al (2007) Comparative study between occult hepatitis $\mathrm{C}$ virus infection and chronic hepatitis C. J Viral Hepat 14:36-40

Pawlotsky JM, Bastie A, Pellet C et al (1996) Significance of indeterminate third-generation hepatitis $\mathrm{C}$ virus recombinant immunoblot assay. J Clin Microbiol 34:80-83

Pawlotsky JM, Lonjon I, Hezode C et al (1998) What strategy should be used for diagnosis of hepatitis $\mathrm{C}$ virus infection in clinical laboratories? Hepatology 27:1700-1702

Pondé RA (2013) Enzyme-linked immunosorbent/chemiluminescence assays, recombinant immunoblot assays and nucleic acid tests in the diagnosis of HCV infection. Eur J Clin Microbiol Infect Dis 32:985-988

Post JJ, Pan Y, Freeman AJ et al (2004) Clearance of hepatitis C viremia associated with cellular immunity in the absence of seroconversion in the hepatitis $\mathrm{C}$ incidence and transmission in prisons study cohort. J Infect Dis 189:1846-1855

Quiroga JA, Llorente S, Castillo I et al (2006) Cellular immune responses associated with occult hepatitis $\mathrm{C}$ virus infection of the liver. J Virol 80:10972-10979

Quiroga JA, Castillo I, Llorente S et al (2009) Identification of serologically silent occult hepatitis $\mathrm{C}$ virus infection by detecting immunoglobulin $\mathrm{G}$ antibody to a dominant $\mathrm{HCV}$ core peptide epitope. J Hepatol 50:256-263

Revie D, Salahuddin SZ (2011) Human cell types important for hepatitis $\mathrm{C}$ virus replication in vivo and in vitro: old assertions and current evidence. Virol J 8:346

Ross RS, Viazov SO, Hoffmann S et al (2001) Performance characteristics of a transcription-mediated nucleic acid amplification assay for qualitative detection of hepatitis $\mathrm{C}$ virus RNA. J Clin Lab Anal 15:308-313

Rossi G, Tucci A, Cariani E et al (1997) Outbreak of hepatitis C virus infection in patients with hematologic disorders treated with intravenous immunoglobulins: different prognosis according to the immune status. Blood 90:1309-1314

Sarhan MA, Pham TN, Chen AY et al (2012) Hepatitis C virus infection of human $\mathrm{T}$ lymphocytes is mediated by CD5. J Virol 86:3723-3735

Schneeberger PM, Keur I, van der Vliet W et al (1998) Hepatitis C virus infections in dialysis centers in The Netherlands: a national survey by serological and molecular methods. J Clin Microbiol 36:1711-1715

Schneeberger PM, Keur I, van Loon AM et al (2000) The prevalence and incidence of hepatitis $\mathrm{C}$ virus infections among dialysis patients in the Netherlands: a nationwide prospective study. J Infect Dis 182:1291-1299

Schreiber GB, Busch MP, Kleinman SH et al (1996) The risk of transfusion-transmitted viral infections. The Retrovirus Epidemiology Donor Study. N Engl J Med 334:1685-1690

Schröter M, Feucht HH, Schäfer P et al (1997) High percentage of seronegative HCV infections in hemodialysis patients: the need for PCR. Intervirology 40:277-278 
Scognamiglio P, Accapezzato D, Casciaro MA et al (1999) Presence of effector $\mathrm{CD}^{+} \mathrm{T}$ cells in hepatitis $\mathrm{C}$ virus-exposed healthy seronegative donors. J Immunol 162:6681-6689

Scott JD, Gretch DR (2007) Molecular diagnostics of hepatitis C virus infection: a systematic review. JAMA 297:724-732

Seyfried H, Brojer E, Grabarczyk P et al (2005) Prevalence of hepatitis C virus markers in Polish blood donors in 1994-2003. Przegl Epidemiol 59:807-814

Sorbi D, Shen D, Lake-Bakaar G (1996) Influence of HIV disease on serum anti-HCV antibody titers: a study of intravenous drug users. J Acquir Immune Defic Syndr Hum Retrovirol 13:295-296

Stapleton JT, Klinzman D, Schmidt WN et al (1999) Prospective comparison of whole-blood- and plasma-based hepatitis $\mathrm{C}$ virus RNA detection systems: improved detection using whole blood as the source of viral RNA. J Clin Microbiol 37:484-489

Stramer SL, Glynn SA, Kleinman SH et al (2004) Detection of HIV-1 and $\mathrm{HCV}$ infections among antibody-negative blood donors by nucleic acid-amplification testing. N Engl J Med 351:760-768

Takaki A, Wiese M, Maertens G et al (2000) Cellular immune responses persist and humoral responses decrease two decades after recovery from a single-source outbreak of hepatitis C. Nat Med 6:578-582

Takedai M, Takatani A, Funato T et al (2008) HCV-RNA test in hepatitis $\mathrm{C}$ virus infection-a systematic review. Rinsho Byori $56: 868-876$

Thimme R, Oldach D, Chang KM et al (2001) Determinants of viral clearance and persistence during acute hepatitis $\mathrm{C}$ virus infection. J Exp Med 194:1395-1406

Thomson BJ (2009) Hepatitis C virus: the growing challenge. Br Med Bull 89:153-167

Thomson EC, Nastouli E, Main J et al (2009) Delayed anti-HCV antibody response in HIV-positive men acutely infected with HCV. AIDS 23:89-93

Troisi CL, Hollinger FB (1997) Detection of antibodies to hepatitis C virus in seronegative patients using an immune complex dissociation assay. J Viral Hepat 4:383-386
Tuaillon E, Mondain AM, Meroueh F et al (2010) Dried blood spot for hepatitis $\mathrm{C}$ virus serology and molecular testing. Hepatology $51: 752-758$

Tugwell BD, Patel PR, Williams IT et al (2005) Transmission of hepatitis $\mathrm{C}$ virus to several organ and tissue recipients from an antibody-negative donor. Ann Intern Med 143:648-654

Urbani S, Amadei B, Fisicaro P et al (2006) Outcome of acute hepatitis $\mathrm{C}$ is related to virus-specific CD4 function and maturation of antiviral memory CD8 responses. Hepatology 44:126-139

Vachon ML, Qazi N, Dieterich DT (2008) HCV treatment challenges in patients co-infected with HIV. HIV Ther 3:87-100

Van der Poel CL, Cuypers HT, Reesink HW et al (1991) Confirmation of hepatitis $\mathrm{C}$ virus infection by new four-antigen recombinant immunoblot assay. Lancet 337:317-319

Wedemeyer H, He XS, Nascimbeni M et al (2002) Impaired effector function of hepatitis $\mathrm{C}$ virus-specific $\mathrm{CD}^{+} \mathrm{T}$ cells in chronic hepatitis C virus infection. J Immunol 169:3447-3458

Wiese M, Berr F, Lafrenz M et al (2000) Low frequency of cirrhosis in a hepatitis $\mathrm{C}$ (genotype 1b). Hepatology 32:91-96

Wright TL, Hollander H, Pu X et al (1994) Hepatitis C in HIVinfected patients with and without AIDS: prevalence and relationship to patient survival. Hepatology 20:1152-1155

Zaghloul H, El-Sherbiny W (2010) Detection of occult hepatitis C and hepatitis $\mathrm{B}$ virus infections from peripheral blood mononuclear cells. Immunol Investig 39:284-291

Zagożdżon P, Parszuto J, Raj A et al (2009) Prevalence and risk factors of chronic hepatitis $\mathrm{C}$ virus infection among health-care workers in Pomeranian voivodeship. Przegl Epidemiol 63:39-43

Zayed RA, Rushdy E, Saleh DA (2010) Detection of HCV RNA in the peripheral blood mononuclear cells of serum HCV RNAnegative Egyptian patients under interferon treatment. Am J Med Sci 340:435-438

Zhang X, Dou J, Germann MW (2009) Characterization of the cellular immune response in hepatitis $\mathrm{C}$ virus infection. Med Res Rev 29:843-866 